\title{
THE ISSUE OF APPLICATION OF PHYSICAL AND CHEMICAL TECHNOLOGIES IN THE DEVELOPMENT OF OIL AND GAS FIELDS
}

\section{• • $\mathbf{x ~ р о в ~ , ~ . ~ • ~ е в ~ н о в , ~ . ~ - ~ р х у т д и н о в ~}$}

E. F. Zakharova, E. V. Levanova, G. N. Farkhutdinov

льметьевский госуд рственный нефтяной институт, г. льметьевск

лючевые слов : метод увеличения нефтеизвлечения, коэффициент нефтеизвлечения; ом шкинское месторождение; ово- лховское месторождение; технологическ я эффективность; обводненность; физико-химические технологии

Key words: increase of oil extraction method; oil extraction coefficient; Romashkinskoe oil field;

Novo-Elkhovskoeoil field; technological efficiency; water cutting; physical and chemical technologies

н стоящее время н месторождениях оссии для увеличения нефтеизвлечения пл стов применяется большое число технологий, позволяющих реш ть 3 д чи регулиров ния охв т вытеснением неоднородных по прониц емости пл стов. р боте [1] уст новлен возможность обеспечения прирост коэффициент извлечения нефти от 0,86 до 4,5 процентов з счет применения ос дкообр зующих композиций н основе неорг нических ре гентов. ри этом подтвержден блокирующий мех низм действия технологии в условиях ряд площ дей и з лежей ом шкинского месторождения, т кже ово- лховского месторождения. ценк по д нным фильтр ционно-емкостных свойств коллекторов, предст вленных средне- и высокопрониц емыми песч ник ми, глинистыми песч ник ми и левролит ми, позволил втор м р боты [1] сдел ть вывод о возможности регулиров ния прониц емости пл ст с применением технологии

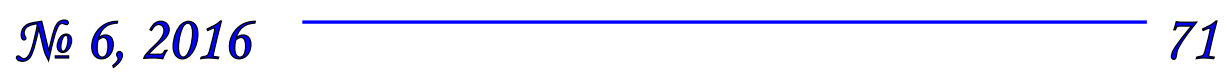


. т рковским [2] р ссмотрены вопросы выр внив ния профиля приемистости ( ) по девяти нефтяным комп ниям оссии при применении потокоотклоняющих технологий, увеличив ющих фильтр ционное сопротивление созд нием гидроизолирующего экр н , который отклоняет фильтр ционные потоки н гнет емой в пл ст воды, в нефтен сыщенные прослои, повыш я · роме этого предложен новый подход к применению технологий перер спределения потоков 3 к чив емой воды.

втором [2] пок з но, что необходимо применение комплекс технологий, н пр вленных н увеличение охв т прослоя з воднением сн ч л по площ ди, з тем по толщине пл ст, используя последов тельно: увеличение охв т пл ст з воднением по площ ди - $\quad$; н гнет тельных скв жин; изоляцию подошвенной воды -

; изоляцию приток воды по высокопрониц емым прослоям в добыв ющей скв жине - ; увеличение приемистости н гнет тельной скв жины; гидрофобиз цию приз бойной зоны скв жины.

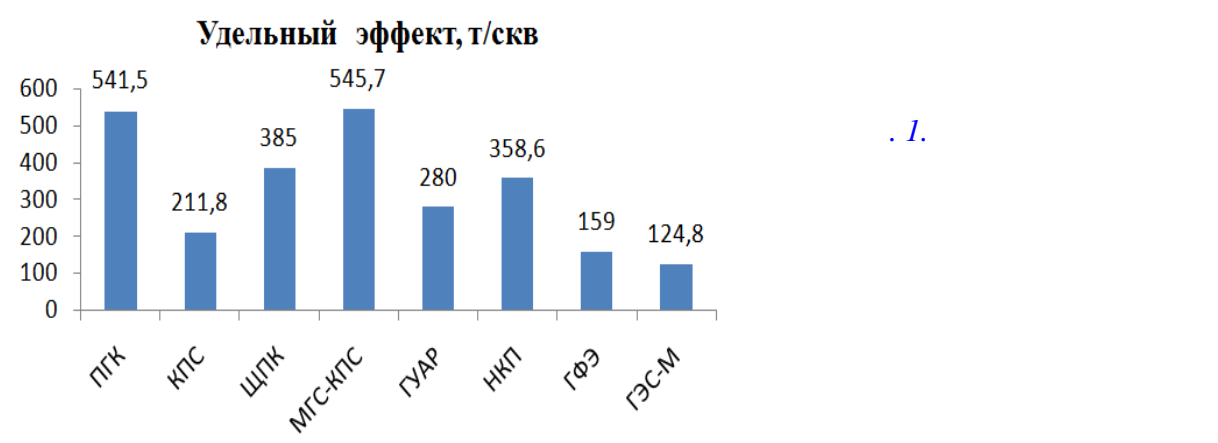

основе н лиз , применяемых н ом шкинском месторождении, втор ми [3] предложен кл ссифик ция, определяем я физико-химическими свойств ми 3 к чив емых технологических жидкостей. p боте [3] уст новлено, что методы, основ нные н повышении фильтр ционного сопротивления обводненных зон нефтеводон сыщенного коллектор з к чив нием полимеров и их модифик ций ( , ,

), н иболее широко н ч ли применяться н поздней ст дии р зр ботки нефтяных месторождений в связи с резким снижением эффективности гидродин мических и физико-химических методов.

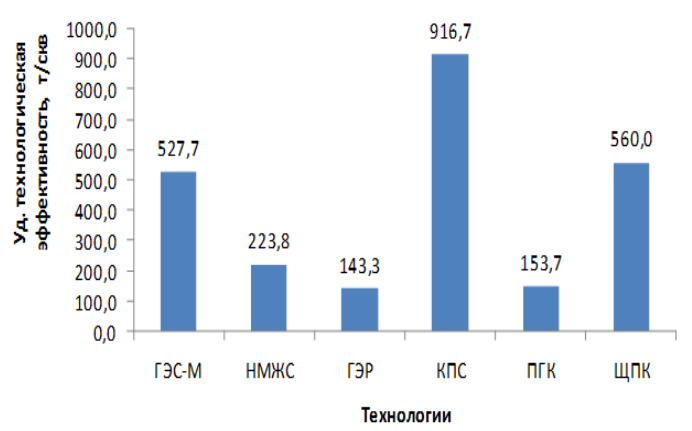

ис. 2. ехнологическ я эффективность

$$
\text { н льметьевской площ, ди }
$$

ом икинского месторождения

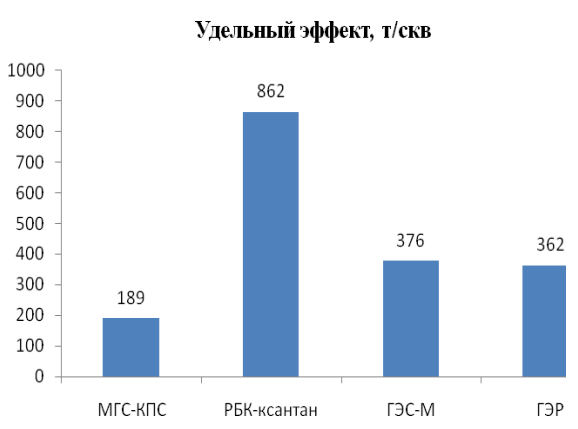

ис. 3. ехнологическ я эффективность

бдр хм новской площ ди ом икинского месторождения

втор ми н стоящей р боты выполнен н лиз технологической эффективности ук $з$ нной группы методов по ряду площ дей ом шкинского и ово- лховского месторождений (рис. 1-6). 
uc. 4.

ехнологическ $я$

эффективность

н шлиярской

площ

ом икинского

месторождения

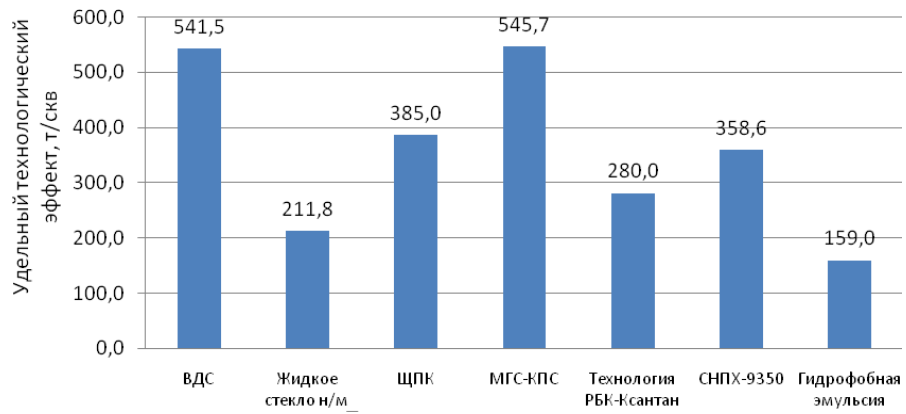

к следует из д нных, предст вленных н рисунк х, технологическ я эффективность технологий

$(545,7$ т) и идрофобной эмульсии (159 т) имеет схожий $\mathrm{x} \mathrm{p} \mathrm{ктер} \mathrm{н} \mathrm{инниб} \mathrm{евской} \mathrm{(рис.} \mathrm{1)} \mathrm{и} \mathrm{шлиярской} \mathrm{(рис.} \mathrm{4)} \mathrm{площ} \mathrm{дях.}$

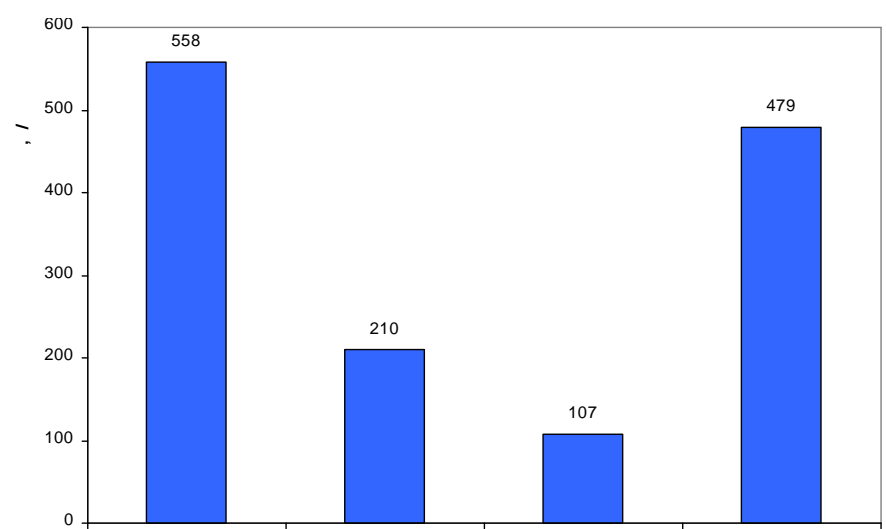

ис. 5. ехнологическ я эффективность н кт шской площ, ди ово- лховского месторождения

ксим льный технологический эффект в 916 т/скв отмечен по технологии $\mathrm{H}$ льметьевской площ ди (рис. 2) и по технологии - $(527,7$ т). ри этом н логичный эффект нельзя отметить по кт шской площ ди (рис. 5).

ис. 6. ехнологическ я эффективность

н ово- лховской площ ди оволховского месторождения

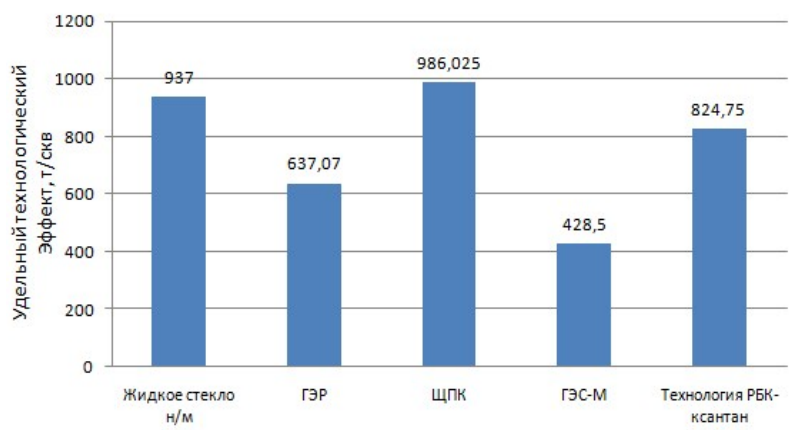

центр льной площ ди ом шкинского месторождения - бдр хм новской (рис. 3) высок я эффективность получен по технологии - с нт н (862 т) и н ово- лховской площ ди ово- лховского месторождения (824,75 т). роме того, н ук $з$ нном объекте ово- лховского месторождения (рис. 6) довольно хорошие пок з тели получены по технологиям и низкомодульного жидкого стекл . ской площ ди ово- лховского месторождения н ибольший удельный технологический эффект получен по технологии 
ким обр зом, результ ты проведенного н лиз

позволяют сдел ть вывод, что при высокой обводненности объектов девонских горизонтов, огр ничение движения вод в высокопрониц емых промытых зон х продуктивного пл ст является одним из гл вных условий повышения эффективности не только з воднения, но и применения физико-химических , основ нных н повышении коэффициент нефтеизвлечения.

есмотря н широкое применение физико-химических методов повышения нефтеизвлечения н поздней ст дии р зр ботки очевидн необходимость их д льнейшей систем тиз ции в 3 висимости от мех низм воздействия н пл ст в конкретных геолого-физических условиях и ст диях р зр ботки.

писок литер туры

1. ехнология увеличения нефтеизвлечения с применением ос дкообр зующих неорг нических ре гентов н месторождениях « тнефть» / _. неев . . лиз ров . . изв нов, ис метдинов/ сборник н учных трудов т т нефть-- вып. LXXXII. - : : ефтяное хозяйство, 2014. - .193-197.

2. омплексное применение физико-химических технологий воздействия для увеличения нефтеотд чи пл стов / . . т рковский // ефтяное хозяйство. - 2011. -№ 5. - С .88-90.

3. сследов ние мех низм воздействия физико-химических методов повышения нефтеотд чи н нефтеводон сыщенный коллектор / . . зизов, . . ебедев, . . л ктионов , . . ис мов. . . мирнов. - : ефтяное хозяйство. -2000 . - № 11. - .16-19.

ведения об втор $x$

х ров лен едоровн, $\kappa, m, н$, доцент, 3 м. з в. к федрой « зр ботк и эксплу т ция нефтяных и г зовых месторождений», льметьевский госуд рственный нефтяной институт, г. льметьевск, тел. 8(8553)310088, e-mail: zakharovaef@yandex.ru

ев нов вгения сильевн, к. федры « зр ботк и эксплу т иия нефтяных и г зовых месторождений», льметьевский госуд рственный нефтяной институт, г. льметьевск, тел. 8(8553)310088, e-mail: evgeniyalevanova@ rambler.ru

рхутдинов ум р " зр ботк и эксплу т иия нефтяных и г зовых месторождений», льметьевский госуд рственный нефтяной институт, тел. 8(8553)310088, e-mail: fargut52@yandex.ru

\section{Information about the author:}

Zakharova $\boldsymbol{E}, \boldsymbol{F}$. Candidate of Engineering Sciences, associateprofessor, vice-head of Department «Development and exploitation of oil and gas fields», Almetyevsk State Oil Institute, Almetyevsk, tel. 8(8553)310088, e-mail: zakharovaef@yandex.ru

Levanova E. V., Candidate of Engineering Sciences, associate professor of Department "Development and exploitation of oil and gas fields», Almetyevsk State Oil Institute, Almetyevsk, tel. 8(8553)310088, e-mail: evgeniyalevanova@rambler.ru

Farkhutdinov G. N., associate professor of Department «Development and exploitation of oil and gas fields», Almetyevsk State Oil Institute, Almetyevsk, tel. 8(8553)310088,e-mail:fargut52@yandex.ru 